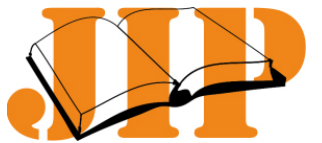

\author{
JURNAL ILMU PEMERINTAHAN: \\ Kajian Ilmu Pemerintahan dan Politik Daerah \\ Volume 4- Nomor 1, April 2019, (Hlm 39-46)
}

Submission: 27-02-2019; Revision: 24-04-2019; Published: 30-04-2019

Available online at: http://e-journal.upstegal.ac.id/index.php/jip

Doi: http://dx.doi.org/10.24905/jip.v4i1.1202

\title{
Akuntabilitas Dana Desa \\ (Kajian Tentang Akuntabilitas Dana Desa Di Kecamatan Masalembu, Kabupaten Sumenep)
}

\author{
Haniah Hanafie ${ }^{\left.{ }^{*}\right)}$, Agus Nugraha ${ }^{2)}$, Masrul Huda ${ }^{3}$ ) \\ 1,2 Program Studi Ilmu Politik, UIN Syarif Hidayatullah Jakarta. Jalan Ir. Juanda No. 95, Ciputat \\ Kota Tangerang Selatan, Banten 15412 Indonesia. \\ 3 Program Studi Akuntansi , UIN Syarif Hidayatullah Jakarta. Jalan Ir. Juanda No. 95, Ciputat Kota \\ Tangerang Selatan, Banten 15412 Indonesia. \\ * Korespondensi e-mail: haniah.hanafie@uinjkt. ac.id
}

\begin{abstract}
Abstrak
Tulisan ini bertujuan untuk mengungkapkan akuntabilitas (pertanggungjawaban) Dana Desa pada Pemerintahan Desa. Pendekatan penelitian bersifat kualitatif. Wawancara, telaah dokumen dan observasi digunakan sebagai teknik pengambilan data. Lokasi penelitian di empat desa di Kecamatan Masalembu, Kabupaten Sumenep, Provinsi Jawa Timur. Deskriptif Analisis digunakan sebagai teknik analisis data dan didukung enam tahapan prosedur pengolahan data. Teori akuntabilitas digunakan sebagai pisau analisis dalam penelitian ini. Hasil penelitian menunjukkan bahwa Akuntabilitas Dana Desa di Kecamatan Masalembu, dilihat dari aspek Keuangan, Manfaat dan Prosedur belum dilaksanakan sebagaimana mestinya.
\end{abstract}

Kata kunci : akuntabilitas; dana desa

Village Funds Accountability:

(Study of The Accountability Of Village Funds In Masalembu Sub District, Sumenep District).

\begin{abstract}
This paper aims to describe accountability of the local Dana Desa at the local level (Masalembu District). Research approaches are qualitative. Interviews, document review and observation are used as data collection techniques. Research sites in four villages in Masalembu District, Sumenep Regency, East Java Province. Descriptive Analysis is used as a data analysis technique and is supported by six stages of data processing procedures. Accountability theory was used as a knife for analysis in this study.The Results of the study indicate that the accountability of village funds in the Masalembu Sub District seen from the financial aspects, benefits and procedures has not implemented yet fully.
\end{abstract}

Keyword: Akuntability; Village funds. 
Jurnal Ilmu Pemerintahan: Kajian Ilmu Pemerintahan dan Ilmu Politik, 4 (1), April

2019- 40

Haniah Hanafie ${ }^{1 *}$ ), Agus Nugraha2), Masrul Huda ${ }^{3)}$

\section{PENDAHULUAN}

Dana Desa (DD) adalah dana untuk desa yang bersumber dari Anggaran Pendapatan dan Belanja Negara (APBN). Sejak tahun 2015, Pemerintah Pusat mulai mengeluarkan anggaran sebesar Rp. 20,76 triliun untuk Dana Desa dan setiap tahun semakin bertambah. Pada tahun 2018, Dana Desa dianggarkan dalam APBN Rp 60

triliun

(https://www.merdeka.com/uang/inialasan pemerintah-jokowi-terus-tambah-jumlah-dana-desa-tiap-tahun.html,

19 Agustus diakses 20 Juli 2018).

Dana Desa diharapkan dapat mensejahterakan dan memeratakan pembangunan bagi masyarakat di pedesaan. Dari hasil penelitian menunjukkan bahwa Dana Desa dapat meningkatkan partisipasi masyarakat desa (Daraba, 2017), kemiskinan di desa dapat dikurangi dan ekonomi masyarakat desa dapat ditingkatkan (Tangkumahat, 2017).

Agar pengelolaan keuangan desa termasuk dana desa dapat mensejahterakan, maka idealnya harus dikelola berdasarkan prinsip-prinsip good governance, yaitu antara lain : transparansi, akuntabilitas, partisipasi dan dilakukan dengan tertib dan disiplin anggaran (Permendagri No. 113 Tahun 2014 tentang Pengelolaan Keuangan Desa).

Namun dari hasil penelitian yang ditemukan KPK (Kholmi, 2016) menunjukkan bahwa akuntabilitas pengelolaan keuangan desa masih rendah. Hal ini dikarenakan kemampuan sumber daya aparatur desa yang masih rendah atau belum kompeten (Asmawati \& Basuki, 2018). Proses yang dilakukan dalam pelaksanaan pembangun belum sesuai aturan Permendagri Nomor
37/2007 (Anifah, Heriyanto, \& Muchid, 2017). Selain itu, masyarakat kurang respon dan kurang pengawasan terhadap pertanggungjawaban pemerintah desa (Putriyanti, Aprisiami, 2012). Oleh karena itu, Pemerintah Desa perlu pendampingan (Kholmi, 2016).

Dari penjelasan di atas, ternyata akuntabilitas menarik untuk dikaji. Banyak Penelitian yang telah dilakukan, Namun penelitian ini dibatasi pada pembahasan tentang Akuntabilitas Keuangan, Akuntabilitas Manfaat dan Akuntabilitas Prosedural.

Tulisan ini didasarkan pada hasil penelitian yang lebih difokuskan pada 3 jenis akuntabilitas yang dikemukakan oleh (R Fajri, 2015) yaitu : Akuntabilitas keuangan, Akuntabilitas manfaat dan Akuntabilitas prosedural.

Pengkajian ini bertujuan untuk melihat bagaimana ketiga jenis akuntabilitas yang dikemukakan Mohamad, dkk dilaksanakan di tingkat desa, khususnya di Kecamatan Masalembu. Dengan harapan agar Dana Desa dapat dipertanggungjawabkan, tidak hanya secara finansial (keuangan), tetapi juga secara manfaat dan proseduralnya.

Akuntabilitas adalah pertanggungjawaban terhadap pelayanan publik yang baik, sebagai bukti unjuk kerja (kinerja) dan pertanggungjawaban tersebut belum tentu diterima, atau bahkan dicela (Frank Bealey dalam (Setyoko, 2011). Membagi akuntabilitas menjadi 3 (tiga) jenis yaitu : Akuntabilitas keuangan, yaitu pertanggungjawaban yang mencakup laporan keuangan yang terdiri dari pendapatan /penerimaan, penyimpanan, serta pengeluaran (R Fajri, 2015). Akuntabilitas manfaat diartikan sebagai pertanggungjawaban yang terkait dengan hasil 


\section{Haniah Hanafie $^{1 *}$ ), Agus Nugraha'), Masrul Huda ${ }^{3)}$}

pencapaian tujuan yang sesuai dengan prosedur dan terpenting dari pencapaian tujuan tersebut adalah efektivitas. Akuntabilitas prosedural dimaksudkan sebagai pertanggungjawaban terkait dengan pentingnya prosedur pelaksanaan dalam mempertimbangkan asas etika, moralitas serta kepastian hukum.

Sedangkan secara spesifik, akuntabilitas juga dapat dilihat dari empat jenis (Wida. SA, Supatmoko. D, Kurrohman, 2017) yaitu : Akuntabilitas Vertikal, Akuntabilitas Horizontal, Akuntabilitas Lokal dan d) Akuntabilitas Sosial.

Dana Desa adalah dana yang bersumber dari APBN yang diperuntukkan bagi Desa yang ditransfer melalui Anggaran Pendapatan dan Belanja Daerah (APBD) Kabupaten/Kota dan digunakan untuk membiayai penyelenggaraan pemerintahan, pelaksanaan pembangunan, pembinaan kemasyarakatan, dan pemberdayaan masyarakat (Permendagri No.113 tahun 2014, Pasal 1 ayat 9).

Tujuan Dana Desa adalah meningkatkan kesejahteraan dan pemerataan pembangunan desa melalui peningkatan pelayanan publik di desa, memajukan perekonomian desa, mengatasi kesenjangan pembangunan antar desa serta memperkuat masyarakat desa sebagai subjek pembangunan.

\section{METODE}

Pendekatan dalam penelitian ini bersifat kualitatif. Pendekatan kualitatif digunakan, untuk menjelaskan fenomena akuntabilitas Dana Desa di Kecamatan Masalembu yang belum tentu dapat didekati dengan pendekatan kuantitatif

Waktu penelitian dilaksanakan pada bulan September-Nopember 2017. Lokasi penelitian dilakukan diempat (4)Desa, yaitu: Desa Sukajeruk, Desa Masakambing, Desa Massalima dan Desa Karamian Kecamatan Masalembu, Kabupaten Sumenep, Provinsi Jawa Timur.

Teknik pengumpulan data berasal dari : 1). wawancara dengan 23 orang Key Informan yang terdiri dari Kepala Desa, Pengurus BPD, Masyarakat (Tokoh Masyarakat/Toma dan Tokoh Agama /Toga), Pendamping, Perangkat Desa (PTPKD), Aparat Desa (Kepala Dusun, RT/RW) dan masyarakat. Teknik Purposive dijadikan sebagai dasar pengambilan narasumber. 2). Observasi, mengamati langsung hasil-hasil pembangunan yang didanai oleh Dana Desa. 3). Telaah dokumen yang terkait dengan UU, PP, PMK, Permendesa yang terkait dengan Dana Desa dan peraturan lainnya.

Tahapan prosedur pengolahan data sebagai berikut (McNabb, 2015) : Gambar 1: A.ProcedureforDataAnalysis

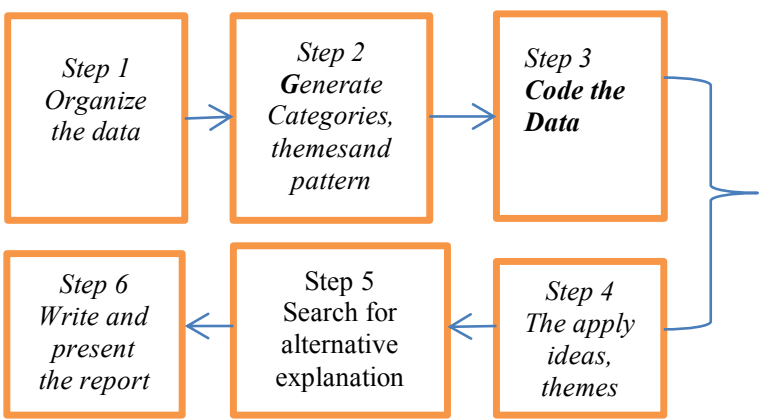

Deskriptif analisis digunakan sebagai teknik analisis dalam penelitian ini, agar dapat mengungkapkan secara jelas fenomena tentang Akuntabilitas Lokal Dana Desa di Kecamatan Masalembu, Kebupatan Sumenep, Provinsi Jawa Timur.

\section{HASIL DAN PEMBAHASAN}

Penelitian Akuntabilitas Dana Desa di Kecamatan Masalembu dideskripsikan melalui Akuntabilitas Keuangan, 
Jurnal Ilmu Pemerintahan: Kajian Ilmu Pemerintahan dan Ilmu Politik, 4 (1), April 2019- 42

Haniah Hanafie ${ }^{1 *}$ ), Agus Nugraha'2), Masrul Huda ${ }^{3)}$

Akuntabilitas Manfaat dan Akuntabilitas Prosedural.

\section{Akuntabilitas Keuangan}

Hasil penelitian menunjukkan, keempat desa: Desa Massalima, Desa Karamian, Desa Sukajeruk dan Desa Masakambing di Kecamatan Masalembu selama dua tahun berturut-turut telah memperoleh Dana Desa dari Pemerintah. Berikut Jumlah Dana Desa diterima keempat desa tersebut tahun 2016 dan 2017:

Tabel 1. Jumlah Dana Desa Diterima Kecamatan Masalembu

\begin{tabular}{lllll}
\hline No & Nama Desa & $\mathbf{2 0 1 6}$ & $\mathbf{2 0 1 7}$ & Jumlah \\
\hline 1. & Massalima & 692.501 .651 & 884.658 .100 & 1.577 .159 .751 \\
& & & & \\
2. & Karamian & 631.899 .240 & 806.211 .300 & 1438.110 .540 \\
3. & Masakambing & 624.660 .278 & 796.840 .800 & 1.421 .501 .078 \\
& & & & \\
4. & Sukajeruk & 669.547 .850 & 854.945 .500 & 1.524 .493 .350 \\
& & & & \\
& Total & $\mathbf{2 . 6 1 8 . 6 0 9 . 0 1 9}$ & $\mathbf{3 . 3 4 2 . 6 5 5 . 7 0 0}$ & $\mathbf{5 . 9 6 1 . 2 6 4 . 7 1 9}$ \\
& & & & \\
\hline
\end{tabular}

Sumber : Data Sekunder Kemendes 2017.

Dana Desa yang diterima oleh keempat desa tersebut di atas, menunjukkan laporan keuangan telah dibuat. Berdasarkan aturan, Dana Desa diturunkan melalui 3 tahap. Setiap tahap, kepala desa harus membuat laporan pertanggungjawaban.

Dari perspektif Akuntabilitas publik, yaitu kewajiban pemerintah melaporkan kepada pemberi mandat (Teguh, 2015) telah dilaksanakan Pemerintah Desa di Kecamatan Masalembu, khususnya dimensi akuntabilitas keuangan dalam bentuk laporan keuangan, sehingga Dana Desa berikutnya dapat diterima oleh Pemerintah Desa.

Namun ditemukan laporan keuangan Dana Desa tidak dibuat sendiri oleh keempat kepala desa, tetapi dibuat oleh konsultan (diistilahkan sebagai "tukang jahit").

Penggunaan istilah "tukang jahit" pernah dilakukan kepala desa pada Program PNPM masa Pemerintahan SBY sebagai jalan pintas di Desa Masalima. Fenomena konsultan atau "tukang jahit" dalam pembuatan laporan keuangan Dana Desa di Kecamatan Masalembu, ternyata ditemui tidak hanya di Desa Masalima, tetapi juga di Desa Karamian.

Di Desa Karamian ditemukan, Pengurus BPD tidak mengetahui tentang masalah pembuatan pelaporan keuangan Dana Desa, karena persoalan itu dianggap urusan kepala desa. Berdasarkan UU No 6 Tahun 2014 tentang Desa, ayat 27 c, Pengurus BPD menerima laporan penyelenggaraan pemerintahan dari kepala desa, termasuk laporan pertanggungjawaban keuangan Dana Desa. Namun BPD Desa Karamian tidak menerima laporan keuangan Dana Desa .

Ketidaktahuan Pengurus BPD ini, menunjukkan akuntabilitas keuangan Pemerintah Desa, khususnya di Desa Karamian, belum direalisasikan dengan baik dan belum terdapat koordinasi antara kepala desa dengan BPD.

Kepala Desa Karamian sebagai penanggungjawab pelaporan keuangan, justru melempar tanggungjawab tersebut kepada Pendamping Lokal Desa (PLD). Sebaliknya, dari pihak PLD tidak membuat laporan keuangan Dana Desa, yang membuat adalah konsultan (tukang jahit).

Temuan BPD tidak menerima laporan keuangan Dana Desa, menunjukkan kepala desa dan PLD tidak transparan kepada masyarakat. Selain itu, ketidakmampuan Pemerintah Desa dalam membuat Laporan Keuangan secara mandiri, menunjukkan akuntabilitas keuangan 
Jurnal Ilmu Pemerintahan: Kajian Ilmu Pemerintahan dan Ilmu Politik, 4 (1), April 2019- 43

\section{Haniah Hanafie ${ }^{1 *}$ ), Agus Nugraha'), Masrul Huda ${ }^{3)}$}

belum mampu direalisasikan dengan baik oleh Pemerintahan Desa di Kecamatan Masalembu. Realisasi akuntabilitas belum sesuai dengan harapan, menurut Aprisiami Putriyanti (2012), penyebabnya karena masyarakat kurang respon terhadap informasi Laporan Penyelenggaraan Desa dan kurang pengawasan terhadap pertanggungjawaban pemerintah desa.

$$
\text { Sedangkan (Irawan, }
$$

menyatakan, penyebab kurangnya akuntabilitas adalah faktor SDM pengelola yang belum mampu membuat pertanggungjawaban administrasi keuangan.

\section{Akuntabilitas Manfaat}

Berdasarkan wawancara dan observasi, Akuntabilitas Manfaat Dana Desa di Kecamatan Masalembu, belum terwujud secara optimal. Berikut fakta di lapangan, yaitu : 1). Pembangunan diskriminatif, 2). Kulitas pembangunan kurang, 3). Pembangunan tidak sesuai kebutuhan masyarakat. Ketiga fakta tersebut menunjukkan akuntabilitas manfaat belum direalisasikan secara optimal.

\section{1) Pembangunan Diskriminatif.}

Berdasarkan wawancara dan observasi, pembangunan yang dibiayai Dana Desa di Kecamatan Masalembu masih diskriminatif, karena pertama, terdapat keberpihakan pembangunan terhadap orang-orang tertentu, misalnya: pembangunan jalan di Dusun Air Hidup, ternyata lokasi pembangunan jalan dekat dengan rumah kepala desa dan perangkat desa.

Kedua, pembangunan tidak didasarkan pada hasil musyawarah, contoh: pembangunan tangkis laut (tembok penahan air laut) di Desa Sukajeruk, ternyata pembangunan tersebut di depan rumah salah seorang kerabat dekat kepala desa. Padahal setiap pembangunan harus didasarkan hasil Musdus (musyawarah dusun) atau Musdes (musyawarah desa).

Pembangunan diskriminatif di atas, dapat membuat masyarakat iri (cemburu) dan menganggap pemerintah desa tidak bersikap adil. Dengan demikian, pemerataan pembangunan sebagai tujuan Dana Desa belum tercapai (UU No 6 tahun 2015 tentang Desa).

\section{2) Kualitas Pembangunan Kurang}

Pembangunan Di Kecamatan Masalembu, yang dibiayai Dana Desa, realitanya dari segi kualitas, belum sesuai dengan spesifikasi, terbukti pembangunan gorong-gorong, selokan-saluran air di Desa Sukajeruk, belum sampai 1 tahun, bangunan tersebut rusak.

Akibat kualitas pembangunan kurang, maka : (a). manfaat pembangunan bagi masyarakat belum optimal, (b). masyarakat merasakan belum puas, (c). kesejahteraan sosial belum dapat dirasakan masyarakat.

\section{3) Pembangunan Belum sesuai Ke- butuhan Masyarakat.}

Pembangunan Papan Nama Desa di pinggir pantai, yang didanai Dana Desa, belum sesuai dengan kebutuhan masyarakat, karena tidak ada keterkaitan secara langsung dengan kesejahteraan masyarakat.

Dengan demikian, pembangunan belum menyentuh program-program peningkatan kesejahteraan, karena belum dibuat skala prioritas yang dibutuhkan masyarakat.

Dari tiga indikator Akuntabilitas Manfaat, 1). Pembangunan bersifat diskriminatif, 2). Kulitas pembangunan kurang, 3). Pembangunan tidak sesuai kebutuhan masyarakat, membuktikan 
Jurnal Ilmu Pemerintahan: Kajian Ilmu Pemerintahan dan Ilmu Politik, 4 (1), April

2019- 44

\section{Haniah Hanafie ${ }^{1 *}$ ), Agus Nugraha ${ }^{2)}$, Masrul Huda ${ }^{3 \text { ) }}$}

bahwa realisasi pembangunan belum efektif, sehingga tujuan pembangunan Dana Desa yang diamanahkan dalam UU No. 6 Tahun 2014 tentang Desa, belum tercapai secara optimal.

Dengan demikian, Akuntabilitas Manfaat Dana Desa di Kecamatan Masalembu, masih belum direalisasikan dengan baik oleh Pemerintah Desa.

\section{Akuntabilitas Prosedur}

Berdasarkan hasil wawancara dan observasi, Akuntabilitas Prosedur Dana Desa di Kecamatan Masalembu masih sulit direalisasikan, karena terdapat penyimpangan dari segi prosedur pelaksanaan dan moralitas.

Bentuk penyimpangan prosedur pelaksanaan Dana Desa, tidak dilibatkannya BPD sebagai perwakilan masyarakat dalam perencanaan Pembangunan Desa yang didanai Dana Desa. Penyimpangan tersebut, terjadi di Desa Sukajeruk dan Masalima.

Masyarakat Sukajeruk, berpendapat bahwa kewibawaan Pengurus BPD lemah, sehingga tidak memiliki kekuatan (power) ketika berhadapan dengan kepala desa. Sedangkan di Desa Masalima, Pengurus BPD juga tidak dilibatkan dalam musyawarah pembahasan anggaran Dana Desa, karena tidak sejalan dengan kepala desa.

Di Desa Sukajeruk dan Masalima, Kepala desa memiliki kekuasaan penuh dalam pengelolaan anggaran Dana Desa. Sedangkan Permendagri No. 114 Tahun 2014 Tentang Pedoman Pembangunan Desa, masyarakat desa berhak melakukan pemantauan terhadap pelaksanaan pembangunan desa. Pemantauan tersebut dapat dilakukan mulai awal perencanaan sampai pelaksanaan. Tahap perencanaan, BPD sebagai perwakilan masyarakat dapat memantau dan berkontribusi dalam penyusunan RPJM dan RKP desa. Di tahap pelaksanaan, BPD dapat mengawasi pengadaan barang, jasa, materiil dan tenaga kerja.

Ketidakterlibatan BPD dan masyarakat dalam pembahasan Dana Desa, baik dalam perencanaan dan pelaksanaan, memperlihatkan pembangunan yang dilaksanakan belum sesuai kebutuhan, karena aspirasi masyarakat tidak diperhatikan, sehingga tujuan pembangunan dari Dana Desa tidak tercapai.

Uraian di atas membuktikan bahwa akuntabilitas prosedur belum dijalankan sesuai dengan Permendagri No. 114 Tahun 2014.

Persolan moralitas sebagai salah satu perspektif Akuntabilitas Prosedur, ditemukan di Desa Sukajeruk, pembangunan tangkis laut, bahan dasarnya diambil dari batu karang, seharusnya menggunakan batu bata. Selain itu, ukuran panjang tangkis laut yang dibangun terlalu pendek.

Penggunaan batu karang sebagai dasar pembangunan tangkis laut menurunkan kualitas, dari segi anggaran menguntungkan bagi penyelenggara, sehingga masyarakat dirugikan.

Penyimpangan yang terjadi di Desa Sukajeruk berkaitan dengan pembangunan tangkis laut, dari perspektif Akuntabilitas Prosedur, merupakan pelanggaran etika dan moral. Seharusnya, menurut (Sadjiarto, 2000), dalam penyelenggaraan akuntabilitas instansi pemerintah, perlu memperhatikan prinsip seperti kejujuran, objektif dan inovatif.

Pelanggaran etika dan moral dalam konteks Akuntabilitas Prosedur, dapat dikenakan sanksi hukum, apabila terbukti bersalah, sebagaimana dikatakan oleh 
Jurnal Ilmu Pemerintahan: Kajian Ilmu Pemerintahan dan Ilmu Politik, 4 (1), April

2019- 45

Haniah Hanafie $^{1 *}$ ), Agus Nugraha2), Masrul Huda ${ }^{3)}$

(Kaihatu, 2006), bahwa salah satu indikator minimum akuntabilitas yaitu adanya sanksi yang ditetapkan atas kesalahan atau kelalaian dalam pelaksanaan kegiatan.

Oleh karena itu, untuk mencegah terjadi penyimpangan atau penegakan akuntabilitas prosedur, diperlukan pengawasan yang ketat, baik dari Pemerintah Kabupaten), masyarakat maupun BPD selaku lembaga musyawarah di desa.

Secara keseluruhan, deskripsi empirik tentang akuntabilitas dana desa di Kecamatan Masalembu memperlihatkan masih lemahnya penerapan prinsip akuntabilitas baik secara finansial, manfaat maupun prosedural. Kondisi tersebut terjadi karena rendahnya kapasitas aparatur pemerintah desa dan belum maksimalnya peran pendampingan yang dilakukan pendamping desa. Hal tersebut karena adanya kendala dalam aspek geografis yakni jarak yang jauh dan sulit dijangkau, serta kendala demografis yakni lemahnya kualitas sumber daya manusia, mengingat rendahnya tingkat pendidikan masyarakat dan aparatur desa. Untuk itu ke depan, tugas pendampingan harus betul-betul dilaksanakan secara maksimal mengingat mereka sudah mendapat anggaran dana desa dari APBN.

\section{SIMPULAN DAN SARAN}

\section{Simpulan}

Dari uraian di atas, dapat disimpulkan bahwa Akuntabilitas Dana Desa, baik dari segi Keuangan, Manfaat dan Prosedur di Kecamatan Masalembu, belum direalisasikan dengan baik.

Pendampingan yang diberikan kepada Pemerintah Desa dalam konteks merealisasikan Akuntabilitas Keuangan, Manfaat dan Prosedur belum maksimal.

Saran

Diperlukan pengawasan yang ketat terhadap pelaksanaan pembangunan desa yang dibiayai Dana Desa, baik dari Pemerintah Kabupaten, BPD dan Masyarakat.

Diberikan sanksi atau teguran yang tegas terhadap pelanggaran/penyimpangan sebagai wujud penegakkan hukum.

Peningkatan Kapasitas aparatur pemerintah desa, perlu dilakukan terus menerus, agar Aparatur Pemerintah Desa dapat mewujudkan akuntabilitas keuangan, Manfaat dan Prosedur.

\section{DAFTAR PUSTAKA}

Anifah, A., Heriyanto, M., \& Muchid, M. (2017). PENGELOLAAN KEUANGAN DESA DALAM MEWUJUDKAN GOOD GOVERNANCE. Ejournal.Unri.Ac.Id.

Asmawati, I., \& Basuki, P. A. R. (2018). Kinerja Pemerintah Desa Dalam Pengelolaan Dana Desa (Studi Pada Desa Dore Kecamatan Palibelo Kabupaten Bima). E-Jurnal Akuntansi Universitas Udayana, 25(3), 2379-2401.

Irawan, N. (2017). Tata Kelola Pemerintahan Desa Era UU Desa - Nata Irawan - Google Books. Retrieved September 17, 2018, from

https://books.google.co.id/books?id=4_ Y8DwAAQBAJ\&printsec $=$ frontcover\&dq =Irawan,+N.+(2017).+Tata+Kelola+Pem erintahan+Desa+Era+UU+Desa.+Yayasa $\mathrm{n}+$ Pustaka+Obor+Indonesia.\&hl=en\&sa $=$ X\&ved $=0$ ahUKEwi414qgrzdAhWBuI8KHfQABoUQ6AEIKTAA\#v= onepage\&q=Irawan $\% 2 C \mathrm{~N} .(20$

Kaihatu, T. (2006). Good corporate governance dan penerapannya di Indonesia. Ced.Petra.Ac.Id, 8(1), 1-9.

Kholmi, M. (2016). Akuntabilitas pengelolaan alokasi dana desa (studi di desa kedungbetik kecamatan kesamben kabupaten jombang). Ekonomika-Bisnis, 07(02), 143-152. 
Jurnal Ilmu Pemerintahan: Kajian Ilmu Pemerintahan dan Ilmu Politik, 4 (1), April 2019- 46

Haniah Hanafie ${ }^{{ }^{*}}$ ), Agus Nugraha'), Masrul Huda ${ }^{3)}$

McNabb, D. (2015). Research methods in public administration and nonprofit management.

R Fajri. (2015). Akuntabilitas Pemerintah Desa pada Pengelolaan Alokasi Dana Desa (Studi Pada Kantor Desa Ketindan, Kecamatan Lawang, Kabupaten Malang). Administrasipublik.Studentjournal.Ub ..., 3(7), 1099-1104.

Sadjiarto, A. (2000). Akuntabilitas dan pengukuran kinerja pemerintahan. Jurnalakuntansi.Petra.Ac.Id, 2(2), 138150.

Setyoko, P. (2011). Akuntabilitas Administrasi Keuangan Program Alokasi Dana Desa (ADD). Jurnal Ilmu Administrasi Negara, 11(1), 14-24.

Teguh, R. (2015). Akuntabilitas Finansial Dalam Pengelolaan Alokasi Dana Desa (Add) di Kantor Desa Perangat Selatan Kecamatan Marangkayu Kabupaten Kutai Kartanegara. Ejournal.an.FisipUnmul.Ac.Id, 3(1), 119-130.

Wida. SA, Supatmoko. D, Kurrohman, T. (2017). Akuntabilitas Pengelolaan Alokasi Dana Desa (ADD) di Desa-Desa Kecamatan Rogojampi Kabupaten Banyuwangi. Jurnal.Unej.Ac.Id, 4(2), 148-152.

\section{Profil Penulis}

Haniah Hanafie

Haniah Hanafie,lahir di Surabaya, 24 Mei 1961, Pendidikan S1 di UNAIR Jurusan Ilmu Politik, S2 di UI Jurusan Ilmu Politik, S3 UB ,Jurusan Administrasi Publik. Saat ini sebagai Dosen Tetap Prodi Ilmu Politik, FISIP UIN Syarif Hidayatullah Jakarta dengan kepangkatan Lektor Kepala

\section{Agus Nugraha}

Agus Nugraha, lahir di Tasikmalaya, 1 Agustus 1968, Pendidikan S1 di UNPAD, Jurusan Administrasi Negara, S2 di UKM Malaysia, Jurusan Political Science, S3 di UB, jurusan Administrasi Publik. Saat ini menjabat Wadek 3 FISIP UIN Syarif Hidayatullah Jakarta dengan pangkat Lektor Kepala.

\section{Masrul Huda}

Masrul Huda, lahir di Surabaya, 6 Mei 1963, Pendidikan S1 di FE UMJ ,Jurusan Akuntansi, S2 UMJ ,jurusan Akuntansi, Saat ini sebagai dosen tetap di FEB UIN Syarif Hidayatullah Jakarta dengan pangkat Asisten Ahli 